\title{
Analysis of Technical Efficiency of Small-Scale Rice Farmers in Indonesia
}

\author{
Fitri Candra Wardana ${ }^{1}$, Naoyuki Yamamoto ${ }^{2}$, Hideyuki Kano ${ }^{2}$
}

${ }^{1}$ Interdisciplinary Graduate School of Agriculture and Engineering, University of Miyazaki, Miyazaki, Japan

${ }^{2}$ Faculty of Agriculture, University of Miyazaki, Miyazaki, Japan

\section{ABSTRACT}

Rice production in Indonesia is depend on rice varieties and cultivation management. Most of Indonesian rice farmer have been using local rices varieties due to the resistance to the extreme enviromental condition and some farmer choose the rice varieties intani- 2 because it can produce high yield. The mechanization is potential solution to enhance the rice production. In this study, we analyzed the performance of small-scale rice farmers who used hand tractors in Jember Regency, Indonesia. Data were collected from 144 small-scale rice farmers in six districts through the use of a questionnaire in September 2015. The Data Envelopment Analysis Slack-Based Model (DEA-SBM) was used to calculate the technical efficiency of small-scale rice farmers based on seven inputs and one output by determining Overall Technical Efficiency (OTE), Pure Technical Efficiency (PTE), and Scale Efficiency (SE). The results showed that out of 144 small-scale rice farmers, only nine farmers and 14 farmers were evaluated as strongly efficient and weakly efficient, respectively, while the rest were categorized as inefficient. The average values for OTE, PTE, and SE were $0.41,0.63$, and 0.61, respectively. The observed inefficiency was because of both poor input utilization (managerial inefficiency) and failure to operate at an optimal scale (scale inefficiency). Such analysis of technical efficiency can encourage small-scale rice farmers to enhance their performance and profitability.

Keywords: Small-scale rice farmers, hand tractor, data envelopment analysis, technical efficiency, Indonesia

\section{INTRODUCTION}

Indonesian small-scale rice farmers are becoming aware of changes from traditional methods in crop production. Rice varieties and environmental condition are the main criteria that related to the rice production. In Indonesia, there are many wet lands that appropriate for rice cultivation. The rice farmer used local and hybrid varieties to improve the yield but farmers cultivate their land using manpower (labor). This influences production costs and long cultivation time.

Therefore, mechanization is one of the solutions to overcome this problem. In Indonesia's case, hand tractors are usually employed for rice field cultivation. With this, the use of hand tractors has an important role in supporting national crop production [1].

Since 1960, the Indonesian government has supported mechanization by launching government programs that distribute free machinery tools and equip-

\footnotetext{
*Corresponding author:

Fitri Candra Wardana

Interdisciplinary Graduate School of Agriculture and Engineering University of Miyazaki

Gakuen-kibanadai-nishi-1-1, Miyazaki, Japan 8892192

E-mail: fitri.candra04@gmail.com
}

ment for small-scale rice farmers.

Specifically, government support includes free hand tractors and hiring schemes to ease access and use of hand tractors. The effect of this program is that the number of hand tractors used by small-scale rice farmers has risen (see Figure 1) $[2,3]$. Based on data from the Centre for Sustainable Agricultural Mechanization, the use of hand tractors in Indonesia increased significantly in 2014 to 192,905 units [3]. Java is one of big five islands with the greatest population in Indonesia. As shown in Figure 1, more than 50 percent of the hand tractors were used in Java, where the field areas are wellirrigated. The rest were scattered outside Java, such as Sumatra, Kalimantan, Bali, Sulawesi, Papua, etc.

Hand tractors help small-scale rice farmers reduce production costs. Decreases in production cost affect profitability, which can be defined as the ability of farmers to use agricultural inputs to garner profits. Farmers

How to cite:

Wardana FC, Yamamoto N, Kano H (2018) Analysis of

Technical Efficiency of Small-Scale Rice Farmers in Indonesia. J.

Trop. Life. Science 8 (1): $91-96$. 


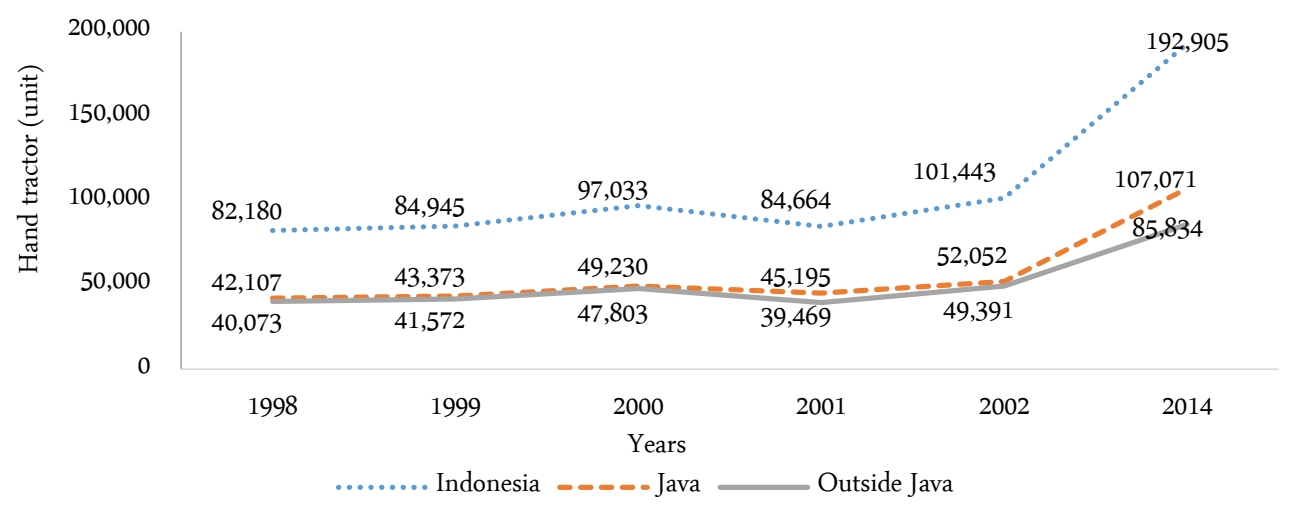

Figure 1. The use of hand tractors in Indonesia (unit) [2, 3]

try to use agricultural inputs as efficiently as possible for maximum income. As a consequence, the use of hand tractors is usually followed by increased employment of other inputs, such as High-Yield Variety (HYV), fertilizers, and fuels. On the other hand, it is also followed by the decreased use of farm labor (number people employed decreases).

However, the effect of the use of hand tractors is different for each farmer. Farmer's income depends on their combined usage of agricultural inputs. The more efficient the agricultural inputs used, the higher the profit (income). Technical efficiency is associated with the role of management in production processes [4]. Technical efficiency can be used to evaluate the performance of small-scale rice farmers when they use agricultural inputs. Therefore, this research is focused on the analysis of technical efficiency of small-scale rice farmers who use hand tractors. In this research, the DEA-SBM approach was applied to assess the technical efficiency of small-scale rice farmers. The efficient hand tractor use is expected to leads to efficient farm labor and efficient agricultural inputs for further. The analysis will determine the efficient farmers who can be role model for inefficient farmers. The results will aid the investigation of the Indonesian government, especially the Ministry of Agriculture, to determine further policy initiatives. By using the result, the Ministry of Agriculture through agricultural field extension officers can assist the inefficient farmers become efficient farmers. Enhancement of farmers ' efficiency is supposed to enhance their profitability.

\section{MATERIALS AND METHODS}

\section{Data collection and sampling method}

Data collection was conducted during September 2015 through questionnaires distributed in Jember regency, East Java, Indonesia (Figure 2). Jember regency is well-known as a major rice production area in East
Java (one of provinces in the island of Java). Based on East Java Food Security Agency and World Food Programme, it led the rice production of East Java from 2004 until 2014 and contributed 978,373 tons (7.89 percent) of $12,398,312$ tons total rice production of East Java in 2014 [5]. Jember regency is located in a lowland area with a slope of 0-2 \%, and therefore, conditions of the area are suitable for application of hand tractors. Most farmers in this region have utilized hand tractors either through ownership or hired schemes. The respondents were randomly selected from six districts, i.e., Bangsalsari, Panti, Sukorambi, Mayang, Silo, and Ledokombo (see Figure 2). Bangsalsari, Panti, and Sukorambi are located in the northern area, while Mayang, Silo, and Ledokombo are located in the eastern area of Jember regency. There are 6238 rice farmers in the six districts. The sample used for analysis of technical efficiency consisted of 144 rice farmers (2.3\%). Based on the survey, the sample (respondents) were classified as small-scale rice farmers because their land size was less than 2 ha (0.63 ha on average). Multistage purposive sampling was used for the selected respondents.

\section{Data Envelopment Analysis (DEA)}

Efficient use of agricultural inputs has the main role in increasing profitability. Therefore, studies on inputoutput patterns on farms are very important. In 2006, Brazdik employed a non-parametric DEA model to evaluate technical and scale efficiency, focusing on measuring and evaluating the efficiency of 160 farms in West Java [6]. The results supported the positive relationship between farm size and technical efficiency.

In 2007, Theocaropoulos et al. included total production costs as the set of inputs in their examination of the agricultural efficiency of Greek sheep farms [7]. Furthermore, they pointed out the appropriateness of inputoriented models. In 2015, Poudel et al. compared tech- 


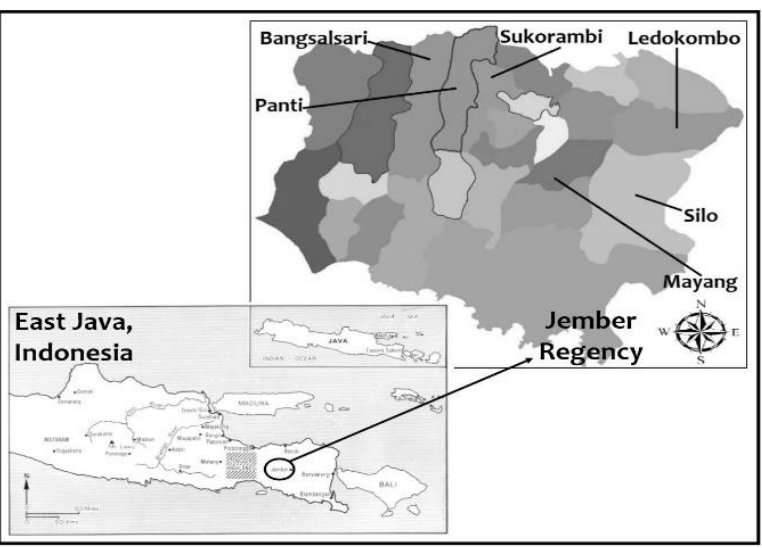

Figure 2. Map of Jember Regency, East Java, Indonesia

nical efficiency among 240 coffee farmers (organic and conventional) in Nepal, finding that the mean of technical efficiency was 0.89 and 0.83 for organic and conventional coffee farming, respectively [8]. The results of their analysis may be used by farmers to reconsider the distribution of their agricultural inputs. Fadzim et al. (2006) estimated technical efficiency of smallholder cocoa farmers in West and East Malaysia, observing farmers in their sample area to be technically inefficient in allocating agricultural inputs [9]. Tipi et al. (2010) investigated the technical efficiency of 70 rice farms in Turkey and featured a Tobit regression to explain inefficiencies in the selected sample [10]. The results demonstrated that farm size and group membership had a positive relationship with efficiency. Kaneva (2016) examined technical efficiency and productivity of Bulgarian farms by using DEA and the Malmquist TFP Index [11]. The study found that land and labor usage were the sources of inefficiencies. Furthermore, the results showed the productivity of Bulgarian farms decreased by $18 \%$ from 2005-2013.

In order to measure technical efficiency of smallscale rice farmers in Jember regency, DEA was applied. DEA was initially introduced by Charnes, Cooper, and Rhodes (CCR) in 1978 [12]. The DEA is a nonparametric method used to measure the performance of Decision Making Unit (DMU). It is also a linear programming model which assumes no random mistakes. DMU refers to production units that produce certain outputs by spending particular inputs. DEA considers many inputs and outputs simultaneously to evaluate the performance of DMU. The main advantage of DEA is that it does not require assumptions about functional forms of the input-output relationship. The DEA construct is the best virtual farmers (frontier) are used to measure efficiencies of real farmers [10]. Efficient DMU is units that employ minimum inputs to achieve a given level output (an in put orientation) or produce optimal output while spending inputs (an output orientation) compared with other units of farmers in the group [13].

Based on the CCR model, the inputs and outputs change proportionally. However, this assumption is not relevant in some cases. Occasionally, under real conditions, the inputs or outputs do not change proportionally. In these situations, the BCC model of Banker et al. (1984) was developed to overcome this problem [14]. The BCC model approach assumes inputs and outputs change disproportionately by adding constraints into the equation [9]. In 2001, Tone proposed an advanced DEA model that measures input excesses and output shortfalls, called "slack" [15].

In the work presented here, the output-oriented DEA-SBM of designed by Tone was applied because basic DEA models based on CCR and BCC models fail to allow additional potential input reductions. An output-oriented model was chosen because farmers like to maximize their output with a given set of inputs. The assumptions of CRS (Constant Return to Scale) and VRS (Variable Return to Scale) were employed to calculate technical efficiency. Various researchers use different indicators (input and output) to calculate technical efficiency. In this study, the DEA model consisted of seven inputs and one output. The selected output was income of small-scale rice farmers per season, while the inputs were production costs, i.e., fertilizer, seeds, pesticides, fuel, labor, hand tractors, and other costs per season (in rupiahs). Other costs considered were tax, irrigation, and transportation. From this analysis, farmers from which district with high efficiency of production costs can be obtained. Further investigation for the efficient farmers from Ministry of Agriculture leads to role modeling.

\section{Technique of analysis}

DEA-SBM was used to assess the performance of each small-scale rice farmer. This model is valuable for calculating technical efficiency differences among smallscale rice farmers with similar technologies (hand tractor). They are measured at the level of inputs and outputs. The model formula provided for DEA-SBM [16]:

$$
\max \left(\lambda, s^{+}, s^{-}\right) \rho=\frac{1-\frac{1}{m} \sum_{i=1}^{m} s_{i}^{-} / x_{\mathrm{oi}}}{1+\frac{1}{s} \sum_{r=1}^{s} s_{r}^{+} / y_{o r}}
$$

Subject to

$$
\begin{gathered}
s^{-}=x_{o}-X \lambda \\
s^{+}=Y \lambda-y_{o}
\end{gathered}
$$


Table 1. Detail output and inputs of 144 small-scale rice farmers

\begin{tabular}{|c|c|c|c|c|c|}
\hline Variable & Unit & Min & $\operatorname{Max}$ & Mean & Standard deviation \\
\hline \multicolumn{6}{|c|}{ Output } \\
\hline Total income & $\mathrm{Rp} /$ season & $2,100,000$ & $58,500,000$ & $18,286,122$ & $9,609,951$ \\
\hline \multicolumn{6}{|c|}{ Inputs } \\
\hline Fertilizer & $\mathrm{Rp} /$ season & 90,000 & $2,765,000$ & 642,160 & 433,684 \\
\hline Seed & $\mathrm{Rp} /$ season & 26,000 & 800,000 & 221,054 & 129,318 \\
\hline Pesticide & $\mathrm{Rp} /$ season & 7,500 & 600,000 & 114,671 & 96,600 \\
\hline Fuel & $\mathrm{Rp} /$ season & 3,700 & 44,400 & 18,221 & 10,063 \\
\hline Labor & $\mathrm{Rp} /$ season & 60,000 & $11,700,000$ & $1,449,676$ & $1,922,975$ \\
\hline Hand tractor & $\mathrm{Rp} /$ season & 90,000 & $2,500,000$ & 525,360 & 357,728 \\
\hline Other cost & Rp/season & 20,000 & $1,650,000$ & 197,064 & 269,364 \\
\hline
\end{tabular}

Note: 1 US\$ $=$ Rp. 14.000 based on average exchange rate in September 2015

Table 2. Technical efficiency score proportion of small-scale rice farmers

\begin{tabular}{lcccc}
\hline Assumption & $\begin{array}{c}\text { Number of effi- } \\
\text { cient farmers }\end{array}$ & $\begin{array}{c}\text { Number of inefficient } \\
\text { farmers }\end{array}$ & $\begin{array}{c}\text { Average efficiency score of inef- } \\
\text { ficient farmers }\end{array}$ & $\begin{array}{c}\text { Average efficiency score of } \\
\text { all farmers }\end{array}$ \\
\hline CRS (OTE) & 9 & 135 & 0.3721 & 0.4113 \\
VRS (PTE) & 22 & 122 & 0.6265 & 0.635 \\
SE & 10 & 134 & 0.5857 & 0.6145 \\
\hline
\end{tabular}

$$
\lambda \geq 0, s^{+} \geq 0, s^{-} \geq 0
$$

The total number of DMU was o $\mid \mathrm{o}=1,2, \ldots, \mathrm{n}$. This assumes that DMU produces 's' desirable outputs out of ' $m$ ' inputs. The values of the inputs of DMU are represented by vector $\mathrm{x}_{0 \mathrm{i}}=\left(\mathrm{x}_{01}, \ldots, \mathrm{x}_{0 \mathrm{~m}}\right)$ and the values of outputs by vector $\mathrm{y}_{0 \mathrm{i}}=\left(\mathrm{y}_{01}, \ldots, \mathrm{y}_{0 \mathrm{~s}}\right)$, where ' $\mathrm{i}$ ' is the number of inputs $(i=1,2, \ldots, m)$ and ' $r$ ' is the number of outputs $(\mathrm{r}=1,2, \ldots, \mathrm{s})$. Furthermore, $\lambda \geq 0$ is a vector assigned to individual productive units; $\mathrm{s}+$ and $\mathrm{s}-$ are vectors of input excesses and output shortfalls, or slacks. The particular value of technical efficiency acquired by a DMU $(\rho)$ is called the efficiency score.

For the DEA-SBM, we used the interval of the efficiency score of $0<\rho \leq 1$ to assess technical efficiency of each DMU. The DMU that acquired a score of less than 1 was considered to operate inefficiently. Technical efficiency under CRS was referred to as OTE. The OTE can be decomposed to PTE and SE. The PTE was measured under the VRS assumption. The SE was calculated as follows:

$$
\mathrm{SE}=\left(\rho_{o}^{C R S}\right) /\left(\rho_{o}^{V R S}\right)
$$

SE was defined by dividing the efficiency score of CRS by the efficiency score of VRS.

\section{RESULTS AND DISCUSSION}

Technical efficiency of rice farmer was evaluated to explain the performance and production cost of traditional rice farmer. Indonesian traditional rice farmer used the local varieties and hybrid varieties such as intani-2. This varieties could survive from to some pest and produce high yield. The biodiversity of rice varieties in Indonesia is diverse. Most of local farmer prefer local varieties than hybrid varieties. Local varieties have specific characteristic to adapt with the environmental condition such as salinity and etc.

The data collection results could be categorized by output and input. Table 1 lists details surrounding output and inputs of 144 small-scale rice farmers. Land size, family labor utilization, and farmers' knowledge affecting production costs (inputs) along with income (output) were accounted for. Based on the output and input data, DEA models were computed using MaxDEA software (Beijing Realworld Software Company Ltd).

The calculation of the efficiency scores using DEA are presented in Table 2. Based on CRS or VRS assumptions, the small-scale rice farmers were categorized as technically efficient farmers if they had efficiency scores of 1 . The results with the CRS (OTE) assumption showed that only nine small-scale rice farmers were technically efficient and operated at best performance. The remaining 135 were technically inefficient.

However, based on VRS (PTE) assumptions, the results indicated that 22 small-scale rice farmers were technically efficient and the remaining 122 were technically inefficient. The SE scores suggested that 10 small-scale 
Table 3. Comparison of CRS, VRS, and SE (strongly efficient and weakly efficient)

\begin{tabular}{|c|c|c|c|c|}
\hline Farmers no. & $C R S$ & $V R S$ & $S E$ & Districts \\
\hline \multicolumn{5}{|c|}{ Strongly efficient } \\
\hline 1 & 1 & 1 & 1 & Silo \\
\hline 2 & 1 & 1 & 1 & Silo \\
\hline 3 & 1 & 1 & 1 & Silo \\
\hline 4 & 1 & 1 & 1 & Silo \\
\hline 5 & 1 & 1 & 1 & Silo \\
\hline 6 & 1 & 1 & 1 & Silo \\
\hline 7 & 1 & 1 & 1 & Silo \\
\hline 8 & 1 & 1 & 1 & Silo \\
\hline 9 & 1 & 1 & 1 & Sukorambi \\
\hline \multicolumn{5}{|c|}{ Weakly efficient } \\
\hline 10 & 0.98 & 0.98 & 1 & Silo \\
\hline 11 & 0.93 & 1 & 0.93 & Silo \\
\hline 12 & 0.59 & 1 & 0.59 & Silo \\
\hline 13 & 0.56 & 1 & 0.56 & Silo \\
\hline 14 & 0.55 & 1 & 0.55 & Silo \\
\hline 15 & 0.54 & 1 & 0.54 & Silo \\
\hline 16 & 0.50 & 1 & 0.50 & Mayang \\
\hline 17 & 0.45 & 1 & 0.45 & Panti \\
\hline 18 & 0.40 & 1 & 0.40 & Panti \\
\hline 19 & 0.40 & 1 & 0.40 & Panti \\
\hline 20 & 0.37 & 1 & 0.37 & Sukorambi \\
\hline 21 & 0.35 & 1 & 0.35 & Sukorambi \\
\hline 22 & 0.29 & 1 & 0.29 & Mayang \\
\hline 23 & 0.23 & 1 & 0.23 & Panti \\
\hline
\end{tabular}

rice farmers were efficient and 134 were inefficient. The calculated average efficiency scores of CRS (OTE), VRS (PTE), and SE for all farmers were 0.41, 0.63, and 0.61, respectively.

CRS (OTE) reflected the aggregate efficiency of DMU, while the VRS (PTE) represented the success of DMU in transforming their inputs into output. This means that VRS (PTE) reflected managerial performance and SE scores were indicative of DMU operating at the most productive scale $($ score $=1$ ) or not. Specifically, DMU was scale efficient when its operations scale was optimal. Based on technical efficiency analysis, small-scale rice farmers with a score of 1 in both VRS (PTE) and SE were categorized as strongly efficient, having the greatest performance among all others (see Table 3). On the other hand, small-scale rice farmers that were weakly efficient had scores of 1 for only VRS (PTE) or SE.

Small-scale rice farmers were categorized as weakly efficient, however, did have opportunities to improve by enhancing their operational management. Furthermore, farmers who failed to reach a score of 1 for CRS (OTE), VRS (PTE), or SE were categorized as inefficient. Of note is that most of the small-scale rice farmers deemed strongly efficient and weakly efficient were from Silo district.

\section{CONCLUSION}

DEA-SBM was used to evaluate the technical efficiency of small-scale rice farmers in Jember regency, Indonesia. Technical efficiency analysis showed that only nine $(6.25 \%)$ farmers were categorized as strongly efficient (best performance). They made the most use of their agricultural inputs (production costs) efficiently, so they may obtain higher income. It was noticed that the inefficiency of small-scale rice farmers was based on both poor agricultural inputs utilization (managerial inefficiency) and failure to operate at optimal scales (scale inefficiency). The weakly efficient and inefficient smallscale rice farmers need to manage their inputs more effectively and elevate their production scale if they expect to achieve higher profitability. Furthermore, the Silo district has the potential for development as a model district.

Based on this research, the Indonesian government, especially the Ministry of Agriculture through agricultural field extension officers, should assist small-scale rice farmers to manage their farms more efficiently. Therefore, further interviews with the nine strongly efficient farmers regarding their inputs management is worthwhile in future work. By the help of agricultural field extension officers, the interviews result will lead the weakly efficient and inefficient small-scale farmers become strongly efficient in the future.

Since hand tractor unavailability leads to high hand tractor cost in each area of the small-scale farmers, hopefully the Ministry of Agriculture can give more support to hiring scheme, such as by giving free or low interest loan of hand tractor to every groups of farmers. As the result, the small-scale farmers can achieve efficient hand tractors and farm labor usage, production costs will be suppressed, and profitability will be increased.

\section{ACKNOWLEDGMENT}

The authors thank to Tonny Pramuharso as head of agricultural field extension officers for his valuable help during data collection in Jember Regency.

\section{REFERENCES}

1. Bappenas (2014) Rencana pembangunan jangka menengah nasional 2015 - 2019. Jakarta, Bappenas. 
2. Statistics Indonesia (2014) Census of agriculture (Various issues), BPS-Statistics Indonesia, 1998-2014. http://www.bps.go.id/. Accessed: March 2017.

3. Unadi A, Alihamsyah T, Budiarti U (2014) Policy on custom hiring of agricultural machinery in Indonesia. Issue No. 4. Beijing, United Nations Centre for Sustainable Agricultural Mechanization.

4. Page JM (1980) Technical efficiency and economic performance: Some evidence from Ghana. Oxford Economic Papers 32 (2): 319 - 339. doi: 10.1093/oxfordjournals.oep.a041482.

5. Badan Ketahanan Pangan Jawa Timur dan World Food Programme (WFP) (2015) Peta Ketahanan dan Kerentanan Pangan Jawa Timur 2015. Surabaya, Badan Ketahanan Pangan Jawa Timur dan World Food Programme (WFP).

6. Brazdik F (2006) Non-parametric analysis of technical efficiency: factors affecting efficiency of West Java rice farms. Working Papers CERGE-EI 286: 1 - 45 . doi: 10.2139/ssrn.1148203

7. Theocaropoulos A, Melfou K, Papanagiotou E (2007) A Microeconomic Approach for Agricultural Development: A DEA Application to Greek Sheep Farms. New Medit 6(4): 48-53.

8. Poudel K, Yamamoto N, Johnson G et al. (2015) Comparing technical efficiency of organic and conventional coffee farms in Nepal using data envelopment analysis (DEA) approach. Organic Agriculture 5 (4): 263 - 275. doi: 10.1007/s13165015-0102-x.
9. Fadzim WR, Aziz MIA, Mat SHC, Maamor S (2016) Estimating technical efficiency of smallholder cocoa farmers in Malaysia. International Journal of Economics and Financial Issues $6(7 \mathrm{~S}): 1-5$.

10. Tipi T, Yildiz N, Nargeleçekenler M, Çetin B (2010) Measuring the technical efficiency and determinants of efficiency of rice (Oryza sativa) farmers in Marmara Region Turkey. New Zealand Journal of Crop and Horticultural Science 37 (2): 121 - 129. doi: 10.1080/01140670909510257.

11. Kaneva K (2016) Efficiency and productivity of Bulgarian farms. Bulgarian Journal of Agricultural Sciences 22 (2): 176 -181 .

12. Charnes A (1978) Measuring the efficiency of decision making units. European Journal of Operational Research 2 (6): 429 - 444. doi: 10.1016/0377-2217(78)90138-8.

13. Vincova $K$ (2005) Using DEA models to measure efficiency. BIATEC, Volume XIII. http://www.nbs.sk/_img/Documents/BIATEC/BIA08_05/24_28. Accessed: March 2017.

14. Banker RD, Charnes A, Cooper WW (1984) Some Models for Estimating Technical and Scale Inefficiencies in Data Envelopment Analysis. Management Science 30 (9): 1078-1092. doi: $10.1287 / \mathrm{mnsc}$ 30.9.1078.

15. Tone K (2001) A Slacks-Based Measure of Efficiency in Data Envelopment Analysis. European Journal of Operational Research 130 (3): 489 - 509. doi: 10.1016/S03772217(99)00407-5.

16. Tone K, Tsutsui M (2009) Network DEA: A slack based measure approach. European Journal of Operational Research 197 (1): 243 - 252. doi: 10.1016/j.ejor.2008.05.027. 